\title{
DNA barcoding reveals a cryptic nemertean invasion in Atlantic and Mediterranean waters
}

\author{
Fernando Ángel Fernández-Álvarez • \\ Annie Machordom
}

Received: 7 October 2012/Revised: 6 January 2013/Accepted: 10 January 2013/Published online: 1 February 2013

(C) Springer-Verlag Berlin Heidelberg and AWI 2013

\begin{abstract}
For several groups, like nemerteans, morphologybased identification is a hard discipline, but DNA barcoding may help non-experts in the identification process. In this study, DNA barcoding is used to reveal the cryptic invasion of Pacific Cephalothrix cf. simula into Atlantic and Mediterranean coasts. Although DNA barcoding is a promising method for the identification of Nemertea, only $6 \%$ of the known number of nemertean species is currently associated with a correct DNA barcode. Therefore, additional morphological and molecular studies are necessary to advance the utility of DNA barcoding in the characterisation of possible nemertean alien invasions.
\end{abstract}

Keywords Alien invasion - DNA barcoding - Nemertea Cephalothrix $\cdot$ Mediterranean Sea $\cdot$ Atlantic Ocean

\section{Introduction}

Morphology-based nemertean taxonomy is a highly specialised discipline: proper fixation and histological procedures are essential for the correct morphological identification in several groups. Most of the material collected during previous marine expeditions was of poor quality for histological studies, due to differences in fixation and anaesthetisation protocols, and thus, the correct identification of those

Communicated by Franke.

\footnotetext{
F. Á. Fernández-Álvarez · A. Machordom ( $₫)$

Museo Nacional de Ciencias Naturales, MNCN-CSIC,

José Gutiérrez Abascal, 2, 28006 Madrid, Spain

e-mail: annie@mncn.csic.es

F. Á. Fernández-Álvarez

e-mail: f.a.fernandez.alvarez@gmail.com
}

specimens has been impeded. Within the Nemertea, the taxon Palaeonemertea is a group that often lacks external morphologically discriminant characters; thus, an anatomical analysis is usually essential. Identification of members of the genus Cephalothrix, composed of 28 named species (Chernyshev 2012), which we analysed here, is based on very subtle and hard-to-interpret characters. However, when morphological identification fails, molecular techniques, using frozen or ethanol-fixed tissues, can be utilised. It is also possible to identify species through DNA barcoding when previous studies with molecular markers have been performed (Darling and Blum 2007; Geller et al. 2010; Roman and Darling 2007). Due to the work of Chen et al. (2010), the genus Cephalothrix is the best-represented genus for cytochrome oxidase I (COI) data in GenBank databases.

In a recent survey of nemertean diversity along the Iberian Peninsula coasts, some morphospecies of Cephalothrix that had not been previously reported in this area were found (Fernández-Álvarez, unpublished data). Although no marine nemertean species has been demonstrated to be an alien invader, Moore et al. (2001) reviewed the role of terrestrial nemerteans in biological invasions associated with ornamental plant commerce. The dispersal capacity of these species may be crucial for understanding its present occurrence in the Iberian coasts. Therefore, understanding the larval development and population structure are important for elucidating this pattern of dispersal. Despite current efforts to study the ontogeny of nemerteans (e.g. Chernyshev 2008; Maslakova 2010a, b; Maslakova and Döhren 2009; Maslakova and Malakhov 1999), many aspects of the biology of nemerteans still remain unclear.

Here, we report a case of a marine nemertean alien invasion, which was confirmed by DNA barcoding studies. 


\section{Materials and methods}

For DNA extraction, 32 individuals of the genus Cephalothrix collected from Iberian Peninsula coasts were preserved in absolute ethanol: seven were from north-western coasts (Atlantic Ocean), and 25 were from north-eastern coasts (Mediterranean Sea). The sampling localities are summarised in Table 1.

The external characters such as colour, shape of the body and gonadal state were drawn, noted and photographed on live animals. In some cases, an internal examination was performed. Three selected specimens were anaesthetised in $7.5 \%$ magnesium chloride and fixed in Bouin's fluid. Paraffin-embedded tissues were cut at $7 \mu \mathrm{m}$. Staining was performed using haematoxylineosin or Para-pak ${ }^{\circledR}$ (Meridian Biosciences) trichrome methods.
Total genomic DNA was extracted from ethanol-fixed tissue from either a fragment of the body or the entire body, depending on the size of the specimen, using the BioSprint 15 DNA kit (Qiagen), following the manufacturers' protocol. We amplified sequences from the partial mitochondrial cytochrome c oxidase I (COI) gene, using the primer pair LCO1490 (Folmer et al. 1994) and COI-H (Machordom et al. 2003). All PCRs were performed in a total volume of $50 \mu \mathrm{l}$ that included $0.3 \mu \mathrm{l}$ of $\mathrm{Taq}$ polymerase $(5 \mathrm{U} / \mu \mathrm{l}$, Biotools), $5 \mu \mathrm{l}$ of reaction buffer (Biotools), $0.8 \mu \mathrm{l}$ of each primer $(10 \mu \mathrm{M}), 1 \mu \mathrm{l}$ of dNTPs $(10 \mathrm{mM})$ and $2 \mu \mathrm{l}$ of template DNA. PCRs consisted of an initial denaturation at $94{ }^{\circ} \mathrm{C}(4 \mathrm{~min})$, followed by 40 cycles of denaturation at $94{ }^{\circ} \mathrm{C}(45 \mathrm{~s})$, annealing at $45{ }^{\circ} \mathrm{C}(90 \mathrm{~s})$ and extension at $72{ }^{\circ} \mathrm{C}(1 \mathrm{~min})$. The amplified fragments (approximately $700 \mathrm{bp}$ ) were purified using ethanol precipitation prior to sequencing both strands on an

Table 1 List of $C$. simula used in this work, including the sample locality, number of specimens analysed $(N)$ and GenBank accession numbers

\begin{tabular}{|c|c|c|c|c|}
\hline Labcode $^{\mathrm{a}}$ & Locality & $N$ & $\begin{array}{l}\text { GenBank } \\
\text { accession number }\end{array}$ & Reference \\
\hline IBE-A1, IBE-A2 & $\begin{array}{l}\text { San Vicente do Mar, O Grove, Galicia, Spain. } \\
42^{\circ} 27^{\prime} \mathrm{N}, 8^{\circ} 55^{\prime} \mathrm{O}^{\mathrm{b}}\end{array}$ & 2 & $\begin{array}{l}\text { JX453463 } \\
\text { JX453464 }\end{array}$ & Present work \\
\hline Vlon005* & $\begin{array}{l}\text { Las Represas beach, Tapia de Casariego, Asturias, Spain. } \\
43^{\circ} 34^{\prime} \mathrm{N}, 6^{\circ} 56^{\prime} \mathrm{O}^{\mathrm{b}}\end{array}$ & 1 & - & Present work \\
\hline Vlon001* & $\begin{array}{l}\text { Los Chalanos beach, Muros de Nalón, Asturias, Spain. } \\
43^{\circ} 23^{\prime} \mathrm{N}, 6^{\circ} 06^{\prime} \mathrm{O}^{\mathrm{b}}\end{array}$ & 1 & - & Present work \\
\hline $\begin{array}{l}\text { IBE-A3, IBE-A4, } \\
\text { Vlon00A* }\end{array}$ & $\begin{array}{l}\text { Aramar beach, Luanco, Asturias, Spain. } \\
43^{\circ} 36^{\prime} \mathrm{N}, 5^{\circ} 46^{\prime} \mathrm{O}^{\mathrm{b}}\end{array}$ & 3 & $\begin{array}{l}\text { JX453465 } \\
\text { JX453466 }\end{array}$ & Present work \\
\hline IBE-A5 to IBE-A7 & $\begin{array}{l}\text { Islares beach, Castro-Urdiales, Cantabria, Spain. } \\
43^{\circ} 24^{\prime} \mathrm{N}, 3^{\circ} 17^{\prime} \mathrm{O}^{\mathrm{b}}\end{array}$ & 3 & $\begin{array}{l}\text { JX453467 } \\
\text { JX453468 } \\
\text { JX453469 }\end{array}$ & Present work \\
\hline IBE-M1, IBE-M2 & $\begin{array}{l}\text { Colera harbor, Cap de Creus, Cataluña, Spain. } \\
42^{\circ} 24^{\prime} \mathrm{N}, 3^{\circ} 09^{\prime} \mathrm{E}^{\mathrm{c}}\end{array}$ & 2 & $\begin{array}{l}\mathrm{JX} 453470 \\
\mathrm{JX} 453471\end{array}$ & Present work \\
\hline IBE-M3 to IBE-M25 & $\begin{array}{l}\text { L'illot del Faradell, Cap de Creus, Cataluña, Spain. } \\
42^{\circ} 20^{\prime} 16^{\prime} \text { N, } 3^{\circ} 16^{\prime} 49^{\prime \prime} \mathrm{E}^{\mathrm{c}}\end{array}$ & 23 & $\begin{array}{l}\text { JX453472 } \\
\text { to } \\
\text { JX453494 }\end{array}$ & Present work \\
\hline JAP-F30 & Fukue, Japan & 1 & GU726622 & Chen et al. (2010) \\
\hline KOR2 & Jeju Island, Korea & 1 & GU726646 & Chen et al. (2010) \\
\hline JAP-O & Oshoro, Japan & 1 & GU726619 & Chen et al. (2010) \\
\hline JAP-SH & Shimoda, Japan & 1 & GU726620 & Chen et al. (2010) \\
\hline JAP-SE3, JAP-SE6 & Seto, Japan & 2 & $\begin{array}{l}\text { GU726661, } \\
\text { GU726662 }\end{array}$ & Chen et al. (2010) \\
\hline ITA & Trieste, Italy & 1 & GU733830 & Chen et al. (2010) \\
\hline $\mathrm{CHI}-\mathrm{C}$ & Changdao, Shandong, China & 1 & GU726615 & Chen et al. (2010) \\
\hline USA-CA1 & San Diego, California, USA & 1 & GU726639 & Chen et al. (2010) \\
\hline
\end{tabular}

All of the Chen et al.'s (2010) specimens correspond to their so-called network 11

* Indicates specimens that were studied only for morphological characterisation

${ }^{a}$ Nomenclature adopted from Chen et al. (2010)

b Atlantic Ocean

${ }^{c}$ Mediterranean Sea 
ABI Prism 3730. The specimens used in this analysis and their labcodes and GenBank accession numbers are summarised in Table 1.

DNA sequences were cleaned at the primer ends using Sequencher (Gene Codes Corporation) and manually aligned. Sequences were then compared with GenBank sequences using BLAST (Altschul et al. 1990). Sequences with the highest similarity were those previously analysed by Chen et al. (2010). Thus, a matrix was generated with both sets of sequences (from this study and Chen et al.'s "network 11"). The haplotype networks were constructed using the software Network 4.5 (www.fluxus-engineering.com), with default parameters with a maximum connectivity limit of $95 \%$. Divergence among haplotypes was calculated in PAUP v4.0a125 (Swofford 2002).

For practical reasons, we used the nomenclature of labcodes adopted in Chen et al. (2010) to name the individuals and the cephalotrichid network (Table 1).

\section{Results}

The haplotype network, with the geographical distribution of the individuals, is provided in Fig. 1. A total of nine haplotypes were found among the samples analysed, five of them in the Iberian Peninsula. The most frequent haplotype was shared by four individuals from the Pacific Ocean (CHI-C, JAP-0, KOR2 and USA-CA1), three individuals from the Atlantic Ocean (IBE-A1, IBE$\mathrm{A} 2$ and IBE-A7) and 18 individuals from the Mediterranean Sea coasts of the Iberian Peninsula (IBE-M2 to IBE-M5, IBE-M7 to IBE-M14, IBE-M16, IBE-M17 and IBE-M20 to IBE-M23). Two haplotypes were present in samples from both Iberian coasts: the first haplotype was found in three individuals from the Atlantic Ocean (IBEA3, IBE-A4 and IBE-A5) and one individual from the Mediterranean Sea (IBE-M1); the second haplotype was found in one Atlantic Ocean individual (IBE-A6) and four Mediterranean Sea individuals (IBE-M15, IBE-M18, IBE-M24 and IBE-M25). Two haplotypes were only found in individuals from the Iberian Mediterranean Sea coasts (IBE-M19 and IBE-M6), while three other haplotypes were found only in Japanese individuals (JAPF30, JAP-SE6 and JAP-SH). The last haplotype was shared by Italian (ITA) and Japanese (JAP-SE3) individuals. The uncorrected divergences among the nine different haplotypes ranged from 0.15 to $0.61 \%$. The mean distance found between the Iberian and Asiatic samples was $0.46 \%$.

The anaesthetised living specimens (Fig. 2) showed the following habitus: sizes between 20 and $60 \mathrm{~mm}$ in length and 0.5 to $0.8 \mathrm{~mm}$ in width; cylindrical body, in some cases flattened in its posterior portion; eyes absent; and a mouth that developed into large lip forming a sucker. Overall, the body was dark yellow, dull orange or reddish yellow, with a brilliant spot of yellow or orange pigment at the tip of the head. The lateral margins were translucent. The ratio of distances from the tip of the head to the brain and the tip of the head to the mouth is between $1: 2.5$ and $1: 3.0$.

Histological analyses demonstrated that the body wall was comprised of typical cephalotrichid muscle layers (Fig. 3a, b), which are formed by an outer circular muscle, an inner longitudinal muscle layer and a thin wall of inner circular musculature formed by two to three muscle fibres around the foregut and the anterior part of the intestine. This form holds a muscle plate between the rhynchocoel and the digestive apparatus (Fig. 3c). Rhynchocoel length was variable; in some cases, it measured more than fourfifths of the total body length. The proboscis sheath was composed of an outer circular and an inner longitudinal muscle layer (Fig. 3c). A type A rhynchocoel vessel was present (Fig. 3a) (following the nomenclature of Kajihara, 2010).

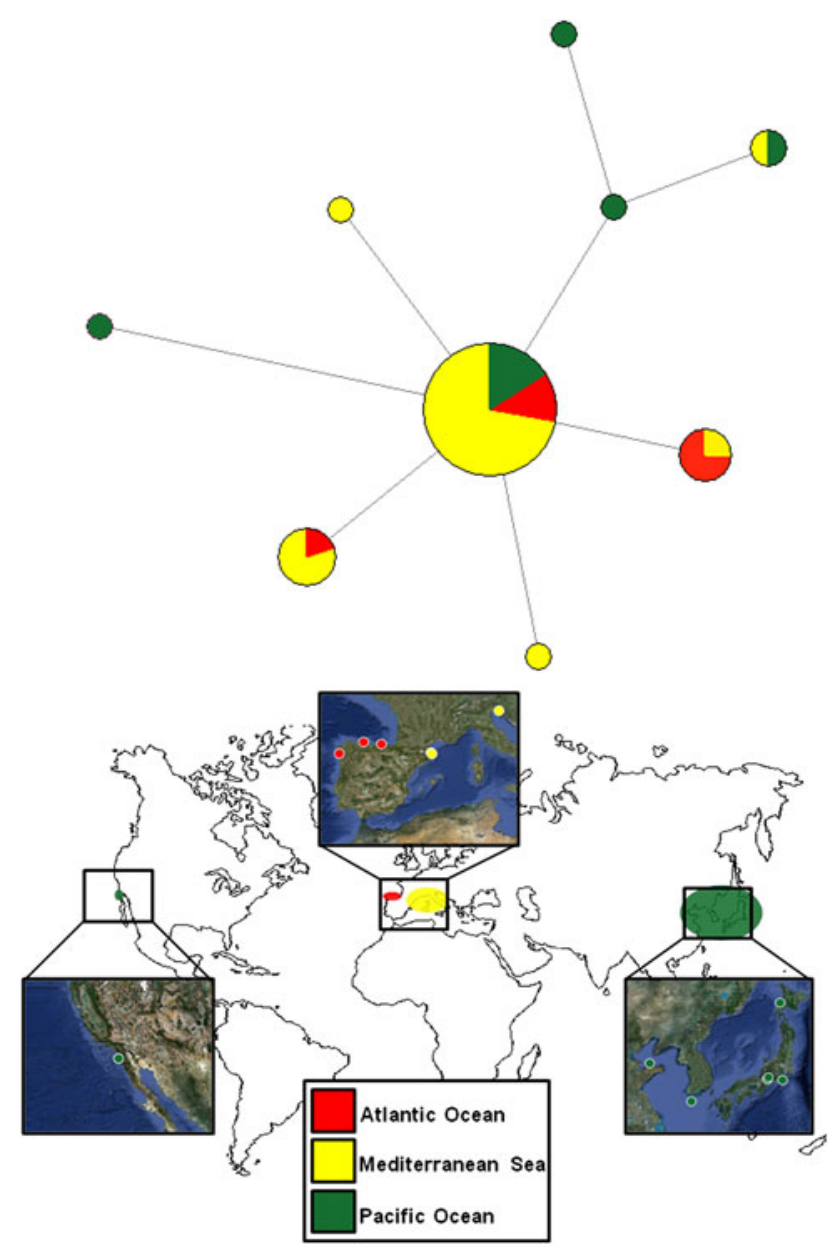

Fig. 1 Haplotype network for the COI haplotypes of $C$. cf. simula. The origin of each sample is indicated in the map. Colours of the haplotype network are consistent with the colours on the map 


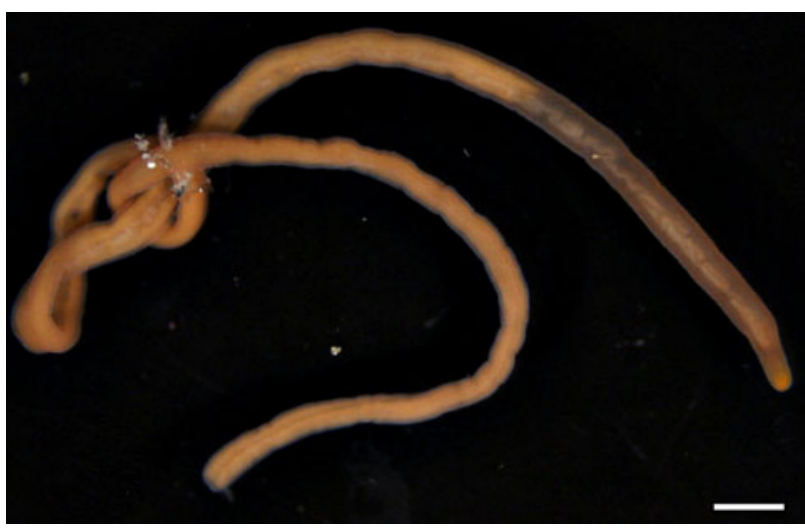

Fig. 2 Habitus of Cephalothrix cf. simula. Scale bar $1 \mathrm{~mm}$

The unpaired buccal nerve (Fig. 3a), which originated posterior to the middle portion of the ventral commissure, ran posteriorly towards the foregut and disappeared immediately behind the mouth. The buccal nerve then branched into two nerves just anterior to the start of the foregut (Fig. 3b).

\section{Discussion}

The dispersal potential of a species is directly related to its biological features (Scheltema 1989; Shuto 1974). In the marine realm, the mode of larval development is one of the main factors that can influence such capacities. Unfortunately, little is known about the ontogeny of Cephalothrichidae; however, the characteristics of the Cephalothrix larvae (Smith 1935; Iwata 1960; Chernyshev 2001) suggest the presence of a lecithotrophic phase. Thus, this type of larvae is thought to have relatively limited dispersal ability. Despite the likely low dispersal ability for this group, we observed several haplotypes that are present both in the Pacific Ocean and in the Atlantic Ocean and Mediterranean Sea (Fig. 1). The observed network showed a main haplotype and several satellite haplotypes (Fig. 1). This structure is frequently associated with a population in expansion with a high level of gene flow. Therefore, this structure is difficult to couple with the supposed low dispersal capacity and the distribution of the populations analysed.

The 32 specimens analysed here clustered in clade 11 of Chen et al. (2010), which is included in a monophyletic group with clades 6 and 8, integrated by Pacific individuals assigned to different species. Chen et al. (2010) concluded that clades 6,8 and 11 contained haplotypes from the same biological species and considered these three networks the result of "undersampling the intraspecific haplotype variation", even if each of these clades represented a separate network. The majority of the specimens analysed and included in these networks were not identified at the species level: only six of the 13 specimens included in clades 6 and 8 were considered to be $C$. simula (Iwata, 1952), while only one specimen in clade 11 was identified as $C$. fasciculus (Iwata, 1952) (Chen et al. 2010, Table S1). However, another specimen identified as $C$. fasciculus was present in clade 22 . Recent unpublished taxonomic work (Kajihara et al., unpublished data) comparing the anatomy of the holotypes of $C$. fasciculus and $C$. simula with the anatomy of the proposed topogenetypes does not reveal any anatomical differences between the two species (Kajihara, pers. comm.). Furthermore, the specimen named "Cephalothrix fasciculus CHI-C" (network 11 in Chen et al. 2010) is from the type locality of $C$. simula, and it is designated as the topogenetype of this species, while the specimen named " $C$. fasciculus JAP-F33" (network 22 in Chen et al. 2010) is designated as the topogenetype of $C$. fasciculus (Kajihara et al., unpublished data). Moreover, the molecular divergence between networks 6, 8 and 11 (K2P $=4.6-9.2 \%$; Chen et al. 2010, Table 2), compared to the intranetwork divergences (K2P between 0 and $0.95 \%$; Chen et al. 2010, Table 1), identified a clear barcoding gap, differentiating three operational taxonomic units (OTUs), since specimens from these three networks occur in sympatry in their original distribution (thus suggesting that reproductive isolation is operating).

An uncertainty surrounds the original descriptions of C. fasciculus and C. simula: in an article from 1952, Iwata differentiated these two taxa by the presence (C. fasciculus) or absence (C. simula) of a muscle plate and by rhynchocoel length, which comprises the entire body length in C. fasciculus. Kajihara (2007) considers that "this character state can be erroneously identified by misinterpretation of a body fragment as an intact specimen". The fragile nature of Cephalothrichidae body tissues and problems related to its preservation support Kajihara's hypothesis. Subsequently, Iwata (1954) reported the presence of a muscle plate between the rhynchocoel and the gut in $C$. simula. The presence of a muscle plate was confirmed in the holotype of C. simula (Kajihara, pers. comm.), thus making the identification of the two species based only on morphological data impossible and the original descriptions invalid (Kajihara et al., unpublished data). Although Iberian specimens exhibited some characters that are inconsistent with the original description of $C$. simula, such as the presence of a muscle plate (Fig. 3c) and the rhynchocoel length, given that morphological descriptions for these two species are not informative for taxonomic proposes, we designate the Iberian specimens as C. cf. simula, since our samples molecularly group with the designated topogenetype (Kajihara, pers. comm.). If we consider clades 6,8 and 11 members of the same nominal species, according to the Chen et al.'s (2010) criterion, then the presence of a clear barcoding gap between these three networks points to the phenomenon of cryptic speciation occurring in these Pacific OTUs under this specific name. 

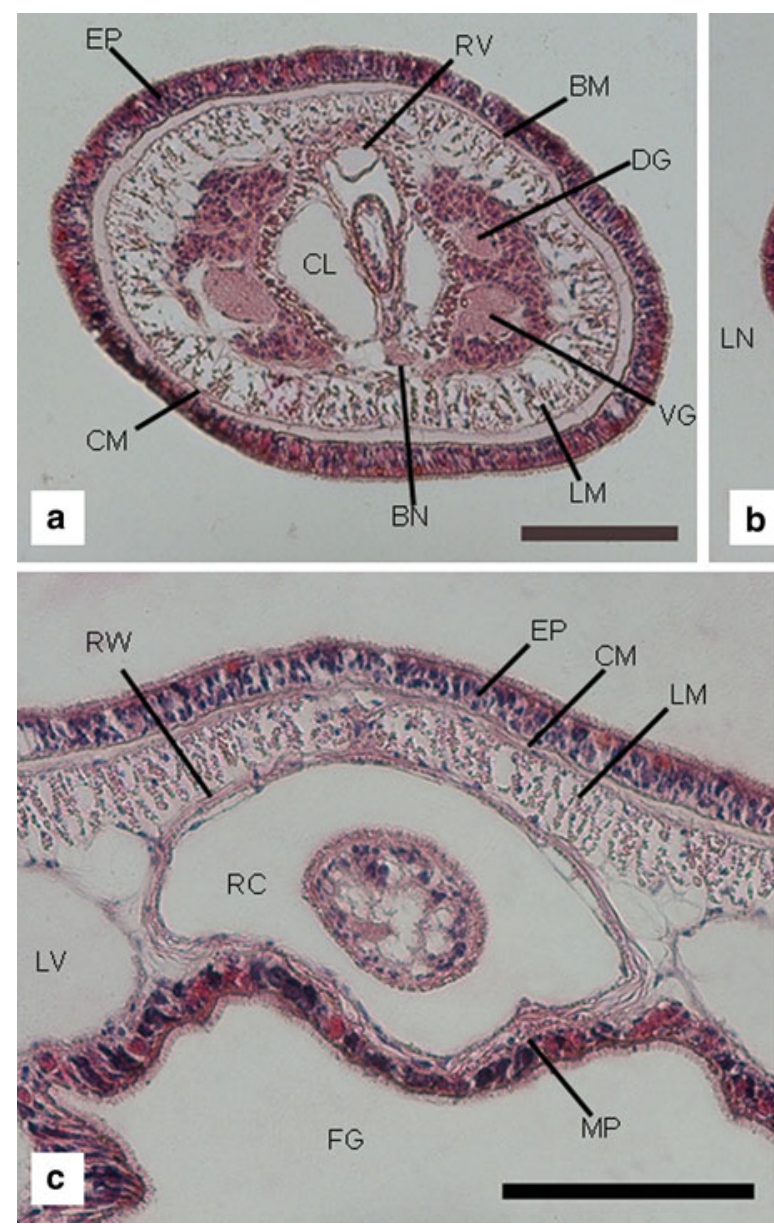

Fig. 3 Cephalothrix cf. simula. Transverse sections through (a) cerebral region, showing the unpaired section of the buccal nerve $(B N)$, (b) buccal region, showing the arrangement of the branched portion of the buccal nerve, (c) intestinal region, showing the muscle plate $(M P)$ and the rhynchocoel wall $(R W)$, (d) intestinal region, showing the arrangement of an incipient ovary $(O V) . B M$ basal membrane,

Although one specimen from Italy was included in the network 11 of Chen et al. (2010), it was not identified at the species level in that study. Moreover, the presence of C. simula has not been previously reported in the Atlantic Ocean. We consider $C$. simula to be an alien invader whose larvae could have been introduced to their allochthonous distribution area in the ballast waters of ships (e.g. Ensis directus in the Iberian Peninsula, Arias and Anadón 2012). The presence of the same haplotypes in different invaded areas and in its natural distribution range suggests several invasion events. The Mediterranean Sea is one of the world's regions most affected by biological invasions (Galil 2009; Zenetos et al. 2010), mainly since the opening of the Suez Canal. However, the presence of $C$. simula from the eastern Mediterranean Sea has not been reported, and the invasion of Atlantic localities cannot be explained by the hypothesis of a Lessepsian migration to the Mediterranean Sea. In this context, it is possible that environmental
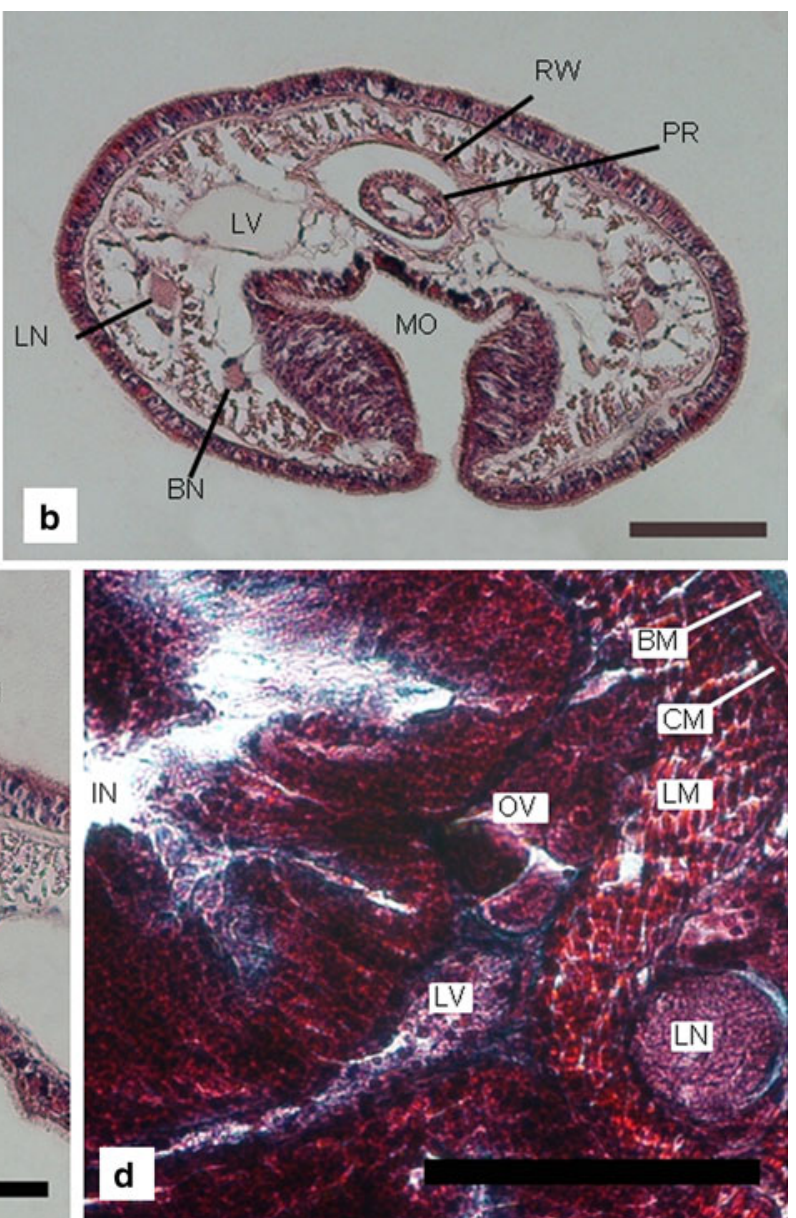

$C L$ cephalic blood lacuna, $C M$ circular muscle layer, $D G$ dorsal ganglion, $E P$ epidermis, $F G$ foregut, $I N$ intestine, $L M$ body wall longitudinal muscle layer, $L N$ lateral nerve cord, $L V$ lateral blood vessel, $P R$ proboscis, $R C$ rhynchocoel, $R V$ rhynchocoel vessel, $V G$ ventral ganglion. Scale bars $100 \mu \mathrm{m}$

changes produced by climate change are currently facilitating the settlement of this species. The presence of developed gonads in one specimen (Fig. 3d) and the presence of juvenile individuals reveal that reproduction is occurring in the invaded areas.

In Colera (Cataluña, Iberian Peninsula), $C$. simula represents $28 \%$ of the nemerteans sampled (FernándezÁlvarez, unpublished data); no other Cephalothrix species were found. Species of the genus Cephalothrix have predatory habits (Wu and Sun 2006), and their introduction into new environments can affect natural populations by competitive exclusion. This invasion has been happening cryptically, and thus, it is possible that it has had several effects on the natural environment. The lack of quantitative data along the Iberian coasts for the majority of nemertean species (e.g. García-Pérez and Anadón 2004) makes it impossible to evaluate whether competitive exclusion is operating on autochthonous Cephalothrix species. 
Our report of $C$. simula along the Iberian coasts is the first record for this species in this local fauna. Currently, the extent of nemertean invasions has only been postulated by Moore et al. (2001) for terrestrial taxa, likely associated with ornamental plants commerce. Turbeville (2011) hypothesised the presence of a population of Emplectonema gracile (Johnston, 1837) in South Carolina as the result of an introduction by ballast waters. However, unlike C. simula, E. gracile has an almost cosmopolitan distribution; it is found in Europe (e.g. North Atlantic and North Sea, Madeira, Black and Mediterranean Seas), Russia (Kamchatka Peninsula), Japan and the two coasts of North America (see Turbeville 2011). This cosmopolitan distribution may indicate a greater dispersal ability for $E$. gracile, but the restricted geographical range of $C$. simula and its sister clade (network 9 in Chen et al. 2010) to Pacific localities, which is a general feature for the genus Cephalothrix, suggests a limited dispersal ability for $C$. simula. The proposed low dispersal ability for $C$. simula supports the hypothesis that this species was introduced outside of its typical geographical range by human-mediated means.

The use of molecular markers (such as COI) to identify cases of nemertean alien invasions is a promising method that may resolve the status of some cryptogenic marine species recorded in the bibliography (e.g. Carlton 1996). Unfortunately, the use of DNA barcoding method is hindered by the fact that only $6 \%$ of the phylum has an associated barcode (Bucklin et al. 2011). For these reasons, we consider the combination of histological and molecular data to be essential for accurately assessing the world's nemertean biodiversity.

Acknowledgments We are grateful to Guillermo San Martín, Nuria Anadón, Luis Ángel Díaz Álvarez, Mario Fernández Pendás and María Fernández Álvarez for providing some samples and for their support in the field. We would like to thank José E. Fernández Alfaya and Ricardo García for their kind support with molecular tools as well as to Nuria Anadón for her help with histological procedures. Anna M. Addamo helped in the construction of haplotype networks. Melinda Modrell revised the English. Thanks to Hiroshi Kajihara and three other anonymous reviewers for their comments. This study was supported by the AECID grants A/023484/09 and A/032441/10.

\section{References}

Altschul SF, Gish W, Miller W, Myers EW, Lipman DJ (1990) Basic local alignment search tool. J Mol Biol 215:403-410

Arias A, Anadón N (2012) First record of Mercenaria mercenaria (Bivalvia: Veneridae) and Ensis directus (Bivalvia: Pharidae) on Bay of Biscay. Iberian Peninsula. J Shellfish Res 31(1):57-60

Bucklin A, Steinke D, Blanco-Bercial L (2011) DNA Barcoding of Marine Metazoa. Annu Rev Mar Biol 3:471-508

Carlton JT (1996) Biological invasions and cryptogenic species. Ecology 77(6):1653-1655

Chen H, Strand M, Norenburg JL, Sun S, Kajihara H, Chernyshev AV, Maslakova SA, Sundberg P (2010) Statistical Parsimony
Networks and Species Assemblages in Cephalotrichid Nemerteans (Nemertea). PLoS ONE 5(9):e12885. doi:10.1371/journal. pone.0012885

Chernyshev AV (2001) The larvae of unarmed nemerteans in Peter the Great Bay (Sea of Japan). Russ J Mar Biol 27(1):58-61

Chernyshev AV (2008) Larval development of nemerteans of the genus Quasitetrastemma (Nemertea: Monostilifera). Russ J Mar Biol 34(4):258-262

Chernyshev AV (2012-In Press) Two new species of deep-sea nemerteans from the SoJaBio expedition in the Sea of Japan. Deep-Sea Res pt II. http://dx.doi.org/10.1016/j.dsr2.2012.07.041

Darling JA, Blum MJ (2007) DNA-based methods for monitoring invasive species: a review and prospectus. Biol Invasions 9: $751-765$

Folmer O, Black M, Hoeh W, Lutz R, Vrijenhoek R (1994) DNA primers for amplification of mitochondrial cytochrome $c$ oxidase subunit I from diverse metazoan invertebrates. Mol Mar Biol Biotech 3:294-299

Galil BS (2009) Taking stock: inventory of alien species in the Mediterranean Sea. Biol Invasions 11:359-372

García-Pérez JA, Anadón N (2004) Seasonal abundance and reproductive strategy of Tetrastemma fozensis Gibson and Junoy, 1991 (Hoplonemertea, Nemertea) in Villaviciosa estuary (Asturias, northern Spain). Estuar Coast Shelf S 60:581-586

Geller JB, Darling JA, Carlton JT (2010) Genetic Perspectives on Marine Biological Invasions. Annu Rev Mar Sci 2:367-393

Iwata F (1952) Nemertini from the Coasts of Kyusyu. J Fac Sci Hokkaido Univ Ser VI 11(1):126-148

Iwata F (1954) The Fauna of Akkeshi Bay: XX. Nemertini in Hokkaido. J Fac Sci Hokkaido Univ Ser VI 12(1-2):1-39

Iwata F (1960) Studies on the comparative embryology of nemerteans with special reference to their interrelationships. Publ Akkeshi Mar Biol Stat 10:1-51

Johnston G (1837) Miscellanea Zoologica II. A description of some planarian worms. Mag Zool Bot 1:529-538

Kajihara H (2007) A Taxonomic Catalogue of Japanese Nemerteans (Phylum Nemertea). Zool Sci 24(4):287-326

Kajihara H (2010) Rhynchocoel vessel in Cephalotrichidae (Nemertea: Palaeonemertea). J Nat Hist 44(37-40):2321-2329

Machordom A, Araujo R, Erpenbeck D, Ramos MA (2003) Phylogeography and conservation genetics of endangered European Margaritiferidae (Bivalvia: Unionoidea). Biol J Linn Soc 78:235-252

Maslakova SA (2010a) The invention of the pilidium larva in an otherwise perfectly good spiralian phylum Nemertea. Integr Comp Biol 50(5):734-743

Maslakova SA (2010b) Development to metamorphosis of the nemertean pilidium larva. Front Zool 7:30

Maslakova SA, Döhren JV (2009) Larval development with transitory epidermis in Paranemertes peregrina and other hoplonemerteans. Biol Bull 216:273-292

Maslakova SA, Malakhov VV (1999) A hidden larva in nemerteans of the order Hoplonemertini. Dokl Biol Sci 366:314-317

Moore J, Gibson R, Jones HD (2001) Terrestrial nemerteans thirty years on. Hydrobiologia 456:1-6

Roman J, Darling JA (2007) Paradox lost: genetic diversity and the success of aquatic invasions. Trends Ecol Evol 22(9):454-464

Scheltema RS (1989) Planktonic and non-planktonic development among prosobranch gastropods and its relationship to the geographical range of species. In: Ryland JS, Tyler PA (eds) Reproduction, Genetics and Distribution of Marine Organisms. 23rd European Marine Biology Symposium. Olsen \& Olsen, Denmark, pp 183-188

Shuto T (1974) Larval ecology of prosobranch gastropods and its bearing on biogeography and paleontology. Lethaia 7:239-256

Smith JE (1935) The Early Development of the Nemertean Cephalothrix rufifrons. Q J Microsc Sci s2-77:335-381 
Swofford DL (2002) PAUP*. Phylogenetic Analysis Using Parsimony (*and Other Methods). Version 4. Sinauer Associates, Sunderland, Massachusetts

Turbeville JM (2011) The first record of Emplectonema gracile (Nemertea. Hoplonemertea) on the Atlantic coast of North America. M Biodiv Rec 4:1-4

Wu B, Sun S (2006) Ammonia and urea excretion of the nemertean Procephalothrix simulus Iwata: effects of salinity, temperature, body weight and amputation. J Ex Mar Biol Ecol 337:13-18
Zenetos A, Gofas S, Verlaque M, Cinar ME, García Raso JE, Bianchi CN, Morri C, Azzurro E, Bilecenoglu M, Froglia C, Siokou I, Violanti D, Sfriso A, San Martín G, Giangrande A, KataganT, Ballesteros E, Ramos-Esplá A, Mastrototaro F, Oca O, Zingone A, Gambi MC, Streftaris N (2010) Alien species in the Mediterranean Sea by 2010. (2010) A contribution to the application of European Union's Marine Strategy Framework Directive (MSFD). Part I. Spatial distribution. Medit Mar Sci 11(2):381-493 